\title{
Experiments and egalitarianism
}

\author{
Shaun P. Hargreaves Heap \\ Department of Political Economy, King's College, London, UK \\ E-mail: s.hargreavesheap@kcl.ac.uk
}

(Received 12 October 2021; accepted 12 October 2021)

\begin{abstract}
In this paper, I reflect on the implications that ultimatum and dictator game experiments might have for public policy and for the debates over egalitarianism. Experiments suggest that people are more inclined to redistribute when outcomes are influenced by luck than effort. This can create difficulties for public policy when people hold contrasting views over whether luck or effort determine outcomes. The results also appear to play into forms of luck egalitarianism. However, they may also be consistent with an alternative understanding of egalitarianism as the impulse to have rules that treat people equally.
\end{abstract}

Keywords: procedural justice; egalitarianism; ultimatum games; luck

\section{Introduction}

Adam Oliver reports on an experiment where the generosity of the 1st mover in an ultimatum game and the willingness of the 2nd mover to accept an offer depends on whether the 1st mover's endowment is a windfall or has been earned through a real effort task. If the endowment has been earned, then the 1st mover is less generous and the 2nd mover's minimum acceptable offer is smaller. Furthermore, the more effort that is required in the task to obtain the endowment, the less generous is the 1st mover and the lower is the 2nd mover's minimum acceptable offer. He draws two related inferences. First, 'effort-based desert matters to people'. Second, since there are often effort-based rewards in real work scenarios, many of the results from games where endowments are windfalls have little policy relevance.

The results of Oliver's experiment fit with that of others (e.g., Hoffman et al., 1994, and in a different but related context, Cappelen et al., 2013) and it contains an important insight about the conditional nature of people's generosity in Ultimatum and Dictator games. I begin by mentioning two possible reservations or qualifications to the second of his inferences. I then argue that his first inference (and the experiment) is of more general significance by placing it in the context of debates in political theory over redistribution.

\section{Two possible reservations/qualifications}

First, does effort significantly account for the inequalities that we observe in the workplace? (c) The Author(s), 2021. Published by Cambridge University Press 
There are other potential determinants: differences in individual skills, bargaining power and the experience of luck. It is possible to argue that effort, skills, and bargaining power can be related to the history of individual choices plus the influence of luck in determining the outcomes of those choices. So, from the rational choice perspective, inequality arises from differences in the preferences that determine choices and the intervention of luck, all organised around dynamics that are likely to exhibit forms of path dependence.

The element of luck might arise at many points in a person's history. Some regard the genes and early environment supplied by parents (and/or others) as a matter of luck. Luck may also arise routinely through being in the right place at the right time' in a market economy. For example, a person who owns property in an area that becomes unexpectedly gentrified could be said to enjoy large capital gains on their property through luck. Likewise, the person who hears about a job because they happened to be at the pub/café/common room/office/water cooler/etc./ at a particular time when there was unexpected discussion of an opening that led to a job is lucky. Most people holding Apple shares from when it was in dire straits in 1997 would admit to getting lucky. Or perhaps, I was lucky to go to a seminar on $\mathrm{X}$ just after reading $\mathrm{Y}$ because it unexpectedly triggered idea $\mathrm{Z}$ that got published in a top journal. In an analogous fashion, those whose manufacturing jobs disappeared because China unexpectedly, from the perspective of the 1980s, became the world's major manufacturer could be said to be unlucky in their choice of career.

In these ways, luck potentially runs through many of our historical decisions that feed into a particular set of outcomes now. People seem to reach different judgements over whether hard work or luck plays the bigger role in such histories. For example, people have been frequently asked to decide on a Likert scale between the statement at one end that 'Long term, hard work usually brings a better life' and the statement at the other end that 'Hard work doesn't generally bring success, luck and connections are more important' (The World Values Survey, for instance, asks this question). European citizens tend to err on the side of luck as compared with those in the US who favour the 'hard work' interpretation (see Alesina \& Angeletos, 2005). Likewise, rich people in a country are more likely to think that hard work is the key compared with the poor, who favour the luck end of the spectrum.

It seems, therefore, that there is no general regularity in how people perceive the relative role of effort and luck in determining incomes. Accordingly, it seems neither an experiment where endowments arise from effort nor one where the endowment is determined by luck can be said generally to approximate better real workplaces. In some settings, one will capture how people perceive incomes are generated, but in some other settings, the other is a better fit; and perhaps in other settings, where views are evenly balanced, neither is a good approximation.

Second qualification: is the fit between the experiment and the real world in this respect all that matters for the relevance of the experiment's results to public policy?

On the usual understanding of external validity, of course, the fit matters deeply. It also matters for the less usual understanding of external validity that turns on interpreting experiments as revealing decision heuristics that are used both in and outside the lab (e.g., see Hargreaves Heap \& Zizzo, 2009). This is because, on this interpretation, the decision heuristic is apparently sensitive to this contextual feature of 
distribution decisions. However, I want to suggest the experiments may also matter for public policy in a manner that does not depend on this fit.

To put this argument in context, one reading of how these experimental results might inform public policy comes from a pragmatic and normative requirement that public policy should reflect citizen preferences. Pragmatically, a public policy that accords with citizen preferences typically enjoys higher compliance than one that does not. Normatively, democratic governance is often thought to enjoy legitimacy because its public policy is more likely to reflect citizen preferences than under other forms of governance. Whatever the reason, if public policy should reflect citizen preferences, then, given these experimental results, when citizens believe hard work determines outcomes, public policy should be less redistributive than when citizens believe luck plays a bigger role. The character of the public policy on redistribution, in other words, is in this way informed by the experimental results.

However, there may be an additional public policy implication or consideration that comes from (1) the fact that the experiments reveal such a difference in redistribution preferences depending on citizens' beliefs about the origins of inequality and (2) the fact that people hold different beliefs about the origins of inequality (referred to above). Public policy may need as a result of this also to be concerned with the accuracy of those beliefs. Had the experiments revealed, for instance, no difference in redistribution preferences across the different possible beliefs about the origins of inequality, then it would not matter for public policy which of these citizens' beliefs about the origin of inequality (luck or hard work) was the more accurate. The accuracy of beliefs only matters for this purpose when something turns on holding a different belief. And this is what the experiment shows: people's redistributive preferences are conditional on the origin of inequality that is presented to them in the experiment.

This might be granted, but nevertheless, one might press: why exactly does accuracy of beliefs matter for public policy in these circumstances in some additional way?

It matters because, given the diversity of views referred to above, whatever public policy on redistribution is selected, it will not accord with some group(s) of citizens' preferences and this threatens compliance and the legitimacy of democratic governance. This is a version of what is sometimes referred to as the problem of 'reality polarisation' (see Alesina et al., 2018). There are enough disputes in politics without manufacturing ones around matters that in principle ought to be resolvable as matters of fact. After all, European and US economies are broadly similar in a variety of key respects (e.g., similar per capita incomes, the dominance of the tertiary sector, the reliance on markets, the provision of publicly funded pensions, etc.), so to hold such disparate views on the origins of inequality points to one or other or both holding in some degree inaccurate beliefs. This is one reason. It may not be easy to dispel inaccuracies, but this can only be tested if public policy accepts there is a problem that needs addressing.

There is another way of bringing out this additional public policy challenge. It draws on an argument from Hayek. He is useful in this respect and I shall draw on him again in the next section. In particular, he suggests, in effect, that people ought 'largely' to see outcomes in a market economy as unforeseeable and in this sense due to accident (or luck). 
The market leaves the particular combination of goods and its distribution among individuals, largely to unforeseeable circumstances - and in this sense to accident. It is, as Adam Smith already understood, as if we agreed to play a game, partly of skill and partly of chance. (Hayek, 2014, p. 310)

This conclusion is buttressed by a further argument he makes when following Smith in locating economic progress with the advancing division of labour. This is because as an economy progresses through the division of labour, what happens in the economy is less and less capable of being understood by any individual. The individual knowledge problem, that Hayek is famous for identifying, is bound to grow with the increasing division of labour and with it the perception that luck or accident is increasingly important.

The more men know, the smaller the share of all that knowledge becomes that any one mind can absorb. The more civilized we become, the more relatively ignorant must each individual be of the facts on which the working of civilization depends. The very division of knowledge increases the necessary ignorance of the individual of most of this knowledge. (Hayek, 1960, p. 78)

If Hayek is right in this latter argument, then the experience in rich countries over the last 40 years is puzzling in ways that pose challenges for public policy. Inequality has typically increased in these countries at the same time as their economies have grown. Following Hayek, and setting aside other considerations, we would therefore expect luck to have paid a growing role in determining outcomes over this 40 years of progress; through an advancing division of labour and with the benefit of the experimental evidence, we further expect that people's preferences, if informed by accurate beliefs on this, should have become less accepting of inequalities. Here, then is the puzzle: inequality has actually increased. There are two broad possible understandings of the tensions in this puzzle. Each sets a different challenge for public policy.

One is that people hold correct beliefs and government policy increasingly failed to keep abreast with changing citizen preferences. There is, as a result, a developing public policy issue over the legitimacy of democratic governance through this growing gap between policy and citizen preferences. Indeed, one might conjecture that such a gap could breed a 'populist' political response of the kind that has been associated with the election of Donald Trump in the US and the Brexit vote in the UK.

Alternatively, government policies did represent citizen views and it is these views that became increasingly inaccurate. They appear to have shifted towards viewing inequality as the result of hard work, and so it became increasingly tolerated, at exactly the time they should have been moving in the opposite direction towards luck. The problem this poses for public policy is that such a growing gap now between beliefs and actuality seems likely to cause a sharp adjustment in beliefs when reality finally intrudes. People sometimes refer to how a piece of elastic stretches and stretches and then suddenly snaps in such circumstances: for example, when a speculative bubble, fuelled by inaccurate beliefs, develops, and then suddenly bursts in financial markets. Democracies typically yield gradual and small policy changes and, indeed, this contributes to why they endure as a form of governance. A different 
challenge, therefore, arises along this alternative understanding of the puzzle: can democracies adjust policy as dramatically and suddenly as a bubble bursting in financial markets if the same thing happens when beliefs finally adjust?

\section{Effort-based desert matters to people}

This is the clear conclusion from Oliver's experiment. In this section, I want to put this conclusion in the context of some broader arguments for and against redistribution.

There is a significant tradition in political philosophy, 'luck egalitarianism', that makes the case for redistribution when there is luck (e.g., see Cohen, 1989; Roemer, 1994; Arneson, 1999). It opposes among others those who have followed Hayek by arguing the reverse: that is, luck provides no grounds for redistribution.

The element of luck is as inseparable from the operation of the market as the element of skill. There is no need morally to justify specific distributions (of income or wealth) which have not been brought about deliberately but are the outcome of a game that is played because it improves the chances of all. (Hayek, 1982, p. 117)

Taking the results at face value, this experiment plays into the hand of the 'luck egalitarians' over the Austrians: people seem more inclined to redistribute when outcomes arise from luck. Before declaring a victory for luck egalitarians, it is worth noting, however, that there is also a debate among egalitarians in political philosophy over what the point of egalitarianism is (see Anderson, 1999); and, in this respect, Oliver's results are less clear in their support of luck egalitarianism. For luck egalitarians, the point of egalitarianism is to prevent or reduce the influence over outcomes of what, from a moral point of view, are arbitrary considerations of luck. For others in the egalitarian tradition, though, the point of egalitarianism is to secure the equal treatment of individuals. Egalitarianism, in other words, is fundamentally about securing equal rights for people: that is, having rules that constrain/ enable action and which, crucially, treat people equally.

From this alternative egalitarian perspective, it is less clear whether 'luck' provides grounds for redistribution because the focus or object of the egalitarian impulse is not outcomes per se and the role of luck in them. Rather, it is the rules/arrangements under which people make decisions - do they treat people equally? If the chances provided by luck were the same for all, then it is not obvious that an outcome following luck's determination provides a reason for redistribution. On the other hand, if people did not have equal chances, an ex post redistribution is potentially warranted as a form compensatory justice for the original inequality in those chances. The critical question for the interpretation of Oliver's experiment in this respect, then, becomes: did the subjects perceive that they had an equal chance of being the 1st mover in the ultimatum game? I don't know the answer to this. However, if they did not, then rule egalitarians would also predict significant redistribution; whereas if they did, the rule egalitarian grounds for redistribution look much weaker and the experiment's results are a challenge. 
What is clear from a rule egalitarian perspective is that it is no surprise that people respond differently in the experiment where the endowment is earned as compared with when it arises from luck. The rules of the game, so to speak, are different in the two cases and it is, therefore, no surprise that people behave differently under the two. From the rule egalitarian perspective, there would be no reason to look at any similarity/dissimilarity in terms of outcomes. What matters in both cases, again, is whether the rules in each case treat people equally and not whether they produce more or less equal/unequal outcomes. If subjects decide to redistribute more under the luck treatment than the real effort task one, then, from the rule egalitarian perspective, this is to be expected if the subjects perceive the real effort task as treating subjects more equally than does the windfall endowment version of the experiment. There is, simply, less need for ex post compensatory redistribution in one than the other.

Again, I cannot judge whether this is at all plausible as an interpretation in the case of the difference in Oliver's experiment. The point behind mentioning these lines of argument is that such experiments potentially resonate within important debates in political philosophy; and this makes for their wider significance.

\section{References}

Alesina, A. and G.-M. Angeletos (2005), 'Fairness and redistribution', American Economic Review, 95: 960-980.

Alesina, A., S. Stantcheva and E. Teso (2018), 'Intergenerational mobility and preferences for redistribution', American Economic Review, 108: 521-554.

Anderson, E. (1999), 'What is the point of equality?' Ethics, 109: 287-337.

Arneson, R. (1999), 'Rawls, responsibility, and distributive justice', in Salles M. and J. A. Wey-mark (eds), Justice, political liberalism, and utilitarianism: Themes from Harsanyi, Cambridge: Cambridge University Press.

Cappelen, A., J. Konow, E. Sorensen and B. Tungodden (2013), 'Just or luck: An experimental study of risk taking and fairness', American Economic Review, 103: 1398-1413.

Cohen, G. A. (1989), 'On the currency of egalitarian justice', Ethics, 99: 906-944.

Hargreaves Heap, S. and D. Zizzo (2009), 'The value of groups', American Economic Review, 99: $295-323$.

Hayek, F. (1960), Constitution of liberty. Chicago: Chicago University Press.

Hayek, F. (1982), 'The market order or catallaxy', in Law, legislation and liberty. London: Routledge.

Hayek, F. (2014), 'Competition as a discovery process', in B. Caldwell (ed.), The collected works of F.A. Hayek, Volume 15: The market and other orders, Chicago: Chicago University Press, 304-313.

Hoffman, E., K. McCabe, K. Shachat and V. Smith (1994), 'Preferences, property rights, and anonymity in bargaining games', Games and Economic Behavior, 7: 346-380.

Roemer, J. (1994) 'A pragmatic theory of responsibility for the egalitarian planner', in Egalitarian perspectives. Cambridge: Cambridge University Press.

Cite this article: Hargreaves Heap SP (2021). Experiments and egalitarianism. Behavioural Public Policy 1-6. https://doi.org/10.1017/bpp.2021.35 